\title{
Identification of plants visited by the honeybee, Apis mellifera L. in the Sudan Savanna zone of northeastern Nigeria
}

\author{
Usman H. Dukku \\ ${ }^{1}$ Biological Sciences Programme, Abubakar Tafawa Balewa University, P.M.B. 0248, Bauchi 740004, Nigeria. \\ ${ }^{2}$ LLH Bieneninstitut Kirchhain, Erlenstrasse 9, 35274 Kirchhain, Germany. \\ Accepted 10 June, 2013
}

\begin{abstract}
A total of 61 species of savanna plants visited by the honeybee, Apis mellifera L. were identified through direct observation of foraging bees. The time of flowering of the plants was also recorded. The largest number of species $(26.2 \%)$ was recorded for the family Fabaceae. Combretaceae ranked second with $9.8 \%$ of the species, while Arecaceae, Lamiaceae, Poaceae Rhamnaceae and Rubiaceae ranked third each with $4.9 \%$ of the species. Each of the remaining families had 2 or 1 species. Many of the species are being reported as bee plants for the first time. An overlap of the periods of flowering of the plants, which made forage available to the bees throughout the year, was observed.
\end{abstract}

Key words: Savanna, bee plants, honeybee plants, bee forage, Apis mellifera, Bauchi, Nigeria.

\section{INTRODUCTION}

The honeybee, Apis mellifera, depends wholly on plants for food. Honeybee workers make thousands of visits to flowers in order to collect nectar and pollen. While doing this they pollinate these flowers, thereby helping to increase fruit and seed-setting both in wild and cultivated plants. The implication of this is that honeybees contribute immensely to the maintenance of ecosystems and agricultural production while they produce important products such as honey. For example, Morse and Calderone (2000) estimated the value of increased yield and quality of crops, due to pollination by honeybees, in the United States of America, for the year 2000, at US $\$ 14.6$ billion. The combined production of honey by the top 20 producer-countries for 2011 was estimated at 1.30 million metric tonnes valued at US $\$ 4.62$ billion (Anonymous, 2013).

According to Hepburn and Radloff (1998), the plants visited by honeybees can be identified through direct observation of foraging bees (Ayansola and Davies,
2012); palynological analysis of honey (Adekanmbi and Ogundipe, 2009); analysis of pollen loads removed from returning foragers (Köppler et al., 2007); and analysis of pollen stores in nests or hives (Ramanujam and Kalpana, 1992). Experienced beekeepers are also an important, albeit secondary source of information on local floral resources (Teklay, 2011).

Recent studies in various ecological zones of Nigeria have revealed a large diversity of honeybee flora in the country. For example, Ayansola and Davies (2012) reported 49 species from the Tropical Rain Forest and Derived Savanna zones of southwestern Nigeria, while Nnamani and Uguru (2012) identified 56 species from the same ecological zones but in southeastern Nigeria. On the other hand, Ebenezer and Olugbenga (2010) and Mbah and Amao (2009) identified 26 and 28 species, respectively, from the Guinea Savanna zone in north central part of the country while Abdullahi et al. (2011) identified 103 species from the Sudan Savanna zone in 
the northeastern part

The knowledge of plants visited by bees is essential in guiding prospective beekeepers in the choice of suitable sites for locating apiaries. It is also essential in the identification of crops that may benefit from pollination by honeybees. This underscores the relevance of the present study aimed at identifying the honeybee flora of the Savanna, an area that is grossly under-studied (Hepburn and Radloff, 1998).

\section{MATERIALS AND METHODS}

\section{The study area}

This study was carried out in Bauchi $\left(9^{\circ} 50^{\prime} \mathrm{E} ; 10^{\circ} 19^{\prime} \mathrm{N} ; 520 \mathrm{~m}\right.$ above sea level) from 1999 to 2010. Bauchi is situated in northeastern Nigeria in the Sudan (dry) Savanna, a belt of vegetation that extends from Senegal to Sudan (Hepburn and Radloff, 1998). Observations were made both in the metropolis and in the outskirts of the city in woodlands, fallows and farmland.

\section{Determination and identification of honeybee plants}

The determination of a plant as a honeybee plant was done through direct observation of foraging honeybee workers on its flowers. These observations were made during field trips, which lasted from dawn to dusk, organized periodically in all seasons. Only plants on which many foragers sustained foraging for nectar and/or pollen were recorded. Some of the plants were photographed with a digital camera. Unfamiliar plants were identified using botanical field guides (Ghazanfar, 1989; Hopkins and Stanfield, 1966; Keay et al., 1964.

\section{RESULTS}

A total of 61 species of plant, grouped into 49 genera and 25 families, were identified as forage plants for $A$. mellifera in the study area (Table 1; Figures 1 to 21). The genus Acacia had the largest number of species $(9.8 \%)$ followed by Combretum (6.6\%) then Ziziphus (4.9\%). The other genera, except Eucalyptus (3.3\%), had one species each. The largest number of species (26.2\%) was recorded for the family Fabaceae. Combretaceae ranked second with $9.8 \%$ of the species, while Arecaceae, Lamiaceae, Poaceae Rhamnaceae and Rubiaceae ranked third each with $4.9 \%$ of the species. Each of the remaining families had 2 or 1 species. The plants were categorized into 41 trees, 6 shrubs and 14 herbs. Seven of the species (Azaderachta indica, Eucalyptus camaldulensis, Eucalyptus torelliana, Mangifera indica, Gmelina arborea, Delonix regia and Tectona grandis) were introduced species. While $41.0 \%$ of the species flower during the major nectar flow period (March to June), $18.0 \%$ flower during the minor one (September to October). On the other hand, while $26.2 \%$ of the species flower during the major dearth period (November February), $14.8 \%$ flower during the minor one (July to August).

\section{DISCUSSION}

The present study identified 61 species of plants foraged by A. mellifera. 32 of these species (Acacia ataxacantha, A. hockii, A. senegal, A. seyal, A. sieberiana, Adansonia digitata, Annona senegalensis, Azadirachta indica, Balanites eagyptiaca, Borassus aetheopum, Carissa edulis, Daniellia oliveri, Delonix regia, Faidherbia albida, Guiera senegalensis, Hymenocardia acida, Isoberlinia doka, Khaya senegalensis, Kigelia africana, Luffa cylindrica, Mangifera indica, Nauclea latifolia, Parkia biglobosa, Tectona grandis, Tridax procumbens, Vernonia amygdalina, Vitellaria paradoxa, Vitex doniana, Ximenia americana, Zea mays, Ziziphus mauritiana and Ziziphus mucronata) were also identified as bee plants, in various vegetation zones of Nigeria, by other workers (Abdullahi et al., 2011; Adekanmbi and Ogundipe, 2009; Ayansola and Davies, 2012; Ebenezer and Olugbenga 2010; Mbah and Amao 2009; Nnamani and Uguru, 2012).

Of the 49 genera reported here, 25 (Acacia, Adansonia, Annona, Bombax, Borassus, Cleome, Combretum, Daniellia, Detarium, Feretia, Guiera, Hymenocardia, Isoberlinia, Kigelia, Nauclea, Parkia, Phoenix, Pterocarpus, Securidaca, Stereospermum, Tamarindus, Terminalia, Vitellaria, Ximenia and Ziziphus) were also reported by Hepburn and Radloff (1998) as important bee plants in the Sudan (dry) Savanna of Africa, north of the equator.

Although, most of the plants (59\%) flower during the nectar flow periods, a large proportion (41\%) flowers during the dearth periods. This provides sufficient food to sustain honeybee colonies, making artificial feeding unnecessary. In fact, in some localities substantial harvests are made even during the dearth periods. An important family to note in this regard is Fabaceae: The blooms of its members, especially Acacia, overlap providing forage throughout the year. The importance of this family is further enhanced by its abundance in the Savanna ecosystem as reported by this study and Mbah and Amao (2009).

Most of the bee plants reported in this study are of continental importance since they are distributed throughout the Savanna. Since the identified plants have uses other than bee forage, apiculture can benefit from other land-use activities involving these plants. These include agriculture (for example, Oryza sativa and Pennisetum typhoides), timber plantations (for example, G. arborea and $T$. grandis), shelter belts and windbreaks (for example, A. indica, E. camaldulensis and $E$. torelliana) and agroforestry (for example, M. indica).

Other plants, such as $B$. aetheopum, Detarium microcarpum, Hyphaene thebaica, $V$. paradoxa, $V$. doniana and $X$. americana, are traditionally spared by farmers for their fruit, while clearing the land for agriculture. Acacia and Combretum are preserved for their gum while $G$. senegalensis is preserved for its medicinalvalue. Still others are planted on farms, compounds 
Table 1. Species of Savanna plants on which Apis mellifera L. was observed foraging at Bauchi, Nigeria.

\begin{tabular}{|c|c|c|c|}
\hline Species & Family & Habit & Bloom $^{*}$ \\
\hline Acacia ataxacantha DC. & Fabaceae & Shrub & 3 \\
\hline Acacia hockii De Willd. & Fabaceae & Shrub & 3 \\
\hline Acacia polyacantha Willd. & Fabaceae & Tree & 1 \\
\hline Acacia senegal (L.)Willd. & Fabaceae & Tree & 1 \\
\hline Acacia seyal Del. & Fabaceae & Tree & 4 \\
\hline Acacia sieberiana DC. & Fabaceae & Tree & 1 \\
\hline Adansonia digitata $\mathrm{L}$. & Bombacaceae & Tree & 1 \\
\hline Annona senegalensis Pers. & Annonaceae & Tree & 1 \\
\hline Azaderachta indica A. Juss & Meliaceae & Tree & 1 \\
\hline Bombax costatum Pellegr. \& Vuill. & Bombacaceae & Tree & 4 \\
\hline Borassus aetheopum Mart. & Arecaceae & Tree & 4 \\
\hline Cassia tora $\mathrm{L}$. & Fabaceae & Herb & 3 \\
\hline Cleome gynandra L. & Capparaceae & Herb & 1 \\
\hline Cochlospermum tinctorium A. Rich & Cochlospermaceae & Herb & 1 \\
\hline Combretum glutinosum Perr. ex DC. & Combretaceae & Tree & 4 \\
\hline Combretum hypopilinum Diels & Combretaceae & Tree & 1 \\
\hline Combretum molle R. Br. ex G. Don & Combretaceae & Tree & 1 \\
\hline Combretum nigrican Lepr. ex Guill. et Perr. & Combretaceae & Tree & 4 \\
\hline Daniellia oliveri (Rolfe) Hutch. \& Dalz. & Fabaceae & Tree & 4 \\
\hline Delonix regia (Boj. ex Hook.) Raf. & Fabaceae & Tree & 1 \\
\hline Detarium microcarpum Guill \& Perr. & Fabaceae & Tree & 2 \\
\hline Eucalyptus camaldulensis Dehnh. & Myrtaceae & Tree & 4 \\
\hline Eucalyptus torelliana F. Muell & Myrtaceae & Tree & 4 \\
\hline Faidherbia albida (Delile) A. Chev. & Fabaceae & Tree & 4 \\
\hline Feretia apodanthera Del. & Rubiaceae & Shrub & 1 \\
\hline Gmelina arborea Roxb. & Verbenaceae & Tree & 4 \\
\hline Guiera senegalensis J.F.Gmel & Combretaceae & Shrub & 3 \\
\hline Hygrophila auriculata Schumach(Heine) & Acanthaceae & Herb & 3 \\
\hline Hymenocardia acida Tul & Euphorbiaceae & Tree & 1 \\
\hline Hyphaene thebaica Mart. & Arecaceae & Tree & 4 \\
\hline Hyptis spicigera Lamarck & Lamiaceae & Herb & 3 \\
\hline Isoberlinia doka Craib \& Stapf & Fabaceae & Tree & 3 \\
\hline Khaya senegalensis (Desr) A Juss & Meliaceae & Tree & 1 \\
\hline Kigelia Africana Lam. & Bignoniaceae & Tree & 4 \\
\hline Luffa cylindrical (L.) Roem. & Cucubitaceae & Herb & 3 \\
\hline Mangifera indica $\mathrm{L}$. & Anacardiaceae & Tree & 4 \\
\hline Mitracarpus scaber Zucc. & Rubiaceae & Herb & 3 \\
\hline Nauclea latifolia Smith & Rubiaceae & Tree & 1 \\
\hline Nymphaea lotus L. & Nymphaeaceae & Herb & 3 \\
\hline Ormocarpum biracteatum (Hochst. Ex. Rich) Bak & Fabaceae & Shrub & 2 \\
\hline Oryza sativa L. & Poaceae & Herb & 3 \\
\hline Parkia biglobosa (Jacq) Benth & Fabaceae & Tree & 1 \\
\hline Pennisetum typhoides (Burm) Stapf \& Hubb. & Poaceae & Herb & 2 \\
\hline Phoenix dactylifera $\mathrm{L}$. & Arecaceae & Tree & 4 \\
\hline Pterocarpus erinaceus Pior. & Fabaceae & Tree & 1 \\
\hline Securidaca longepedunculata Fres. & Polygalaceae & Tree & 1 \\
\hline Stereospermum kunthiamum Cham. & Bignoniaceae & Tree & 1 \\
\hline Tamarindus indica $\mathrm{L}$. & Fabaceae & Tree & 1 \\
\hline Tectona grandis L. & Verbenaceae & Tree & 2 \\
\hline Terminalia laxiflora Engl. & Combretaceae & Tree & 1 \\
\hline
\end{tabular}


Table 1. Contd.

\begin{tabular}{llll}
\hline Tridax procumbens L. & Asteraceae & Herb & 2 \\
Vernonia amygdalina Del. & Asteraceae & Herb & 4 \\
Vitellaria paradoxa Gaertn. & Sapotaceae & Tree & 1 \\
Vitex doniana Sweet & Lamiaceae & Tree & 1 \\
Vitex simplicifolia Oliv. & Lamiaceae & Tree & 1 \\
Waltheria indica L. & Sterculiaceae & Herb & 2 \\
Ximenia americana L. & Olacaceae & Shrub & 1 \\
Zea mays L. & Poaceae & Herb & 2 \\
Ziziphus mauritiana Lamarck & Rhamnaceae & Tree & 2 \\
Ziziphus mucronata Willd. & Rhamnaceae & Tree & 2 \\
Ziziphus spina-christi (L.) Desf. & Rhamnaceae & Tree & 4 \\
\hline
\end{tabular}

*Period during which the plants flower, as defined by Dukku (2003). 1: Major nectar flow period (March to June); 2: Minor dearth period (July to August); 3: Minor nectar flow period (September to October); 4: Major dearth period (November to February).

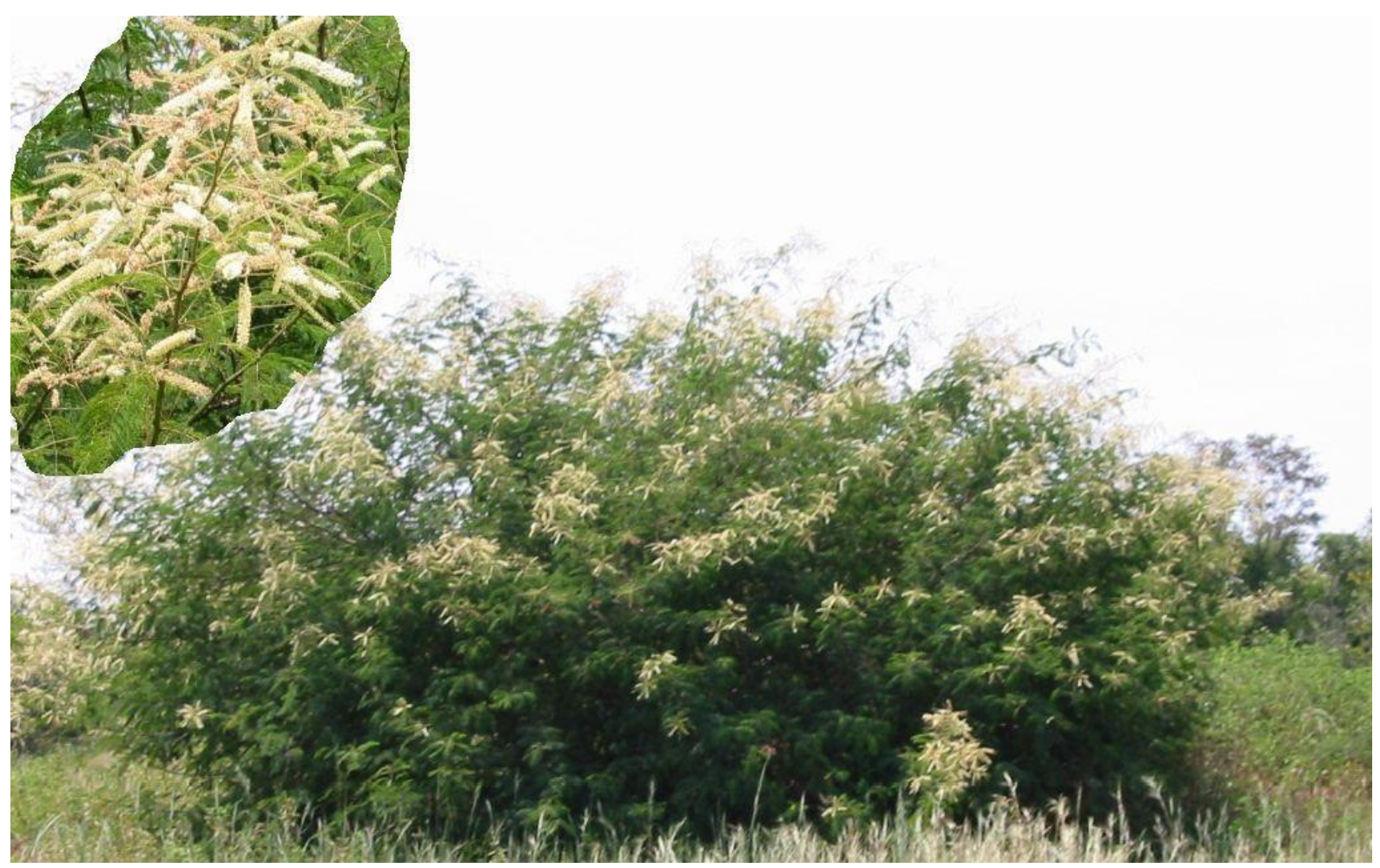

Figure 1. Acacia ataxacantha DC.

or in streets to provide fruit (for example, Phoenix dactylifera and $P$. biglobosa), shade (for example, $K$. senegalensis) or as ornamentals (for example, D. regia). A notable species with multiple uses is Adansonia digitata which yields vegetable, fibre, fruit and traditional herbal medicine, in addition to being an important bee plant.

In conclusion, it is suggested that further studies should be carried out on bee-plant relationships in view of identi- fying more forage plants for honeybees in the Savanna.

\section{ACKNOWLEDGEMENTS}

I wish to acknowledge, with thanks, the assistance given to me in the field by my student, Mr. Albert Domo, and Mr. Babayo K. Musa of the Biological Sciences Programme, Abubakar Tafawa Balewa University. 


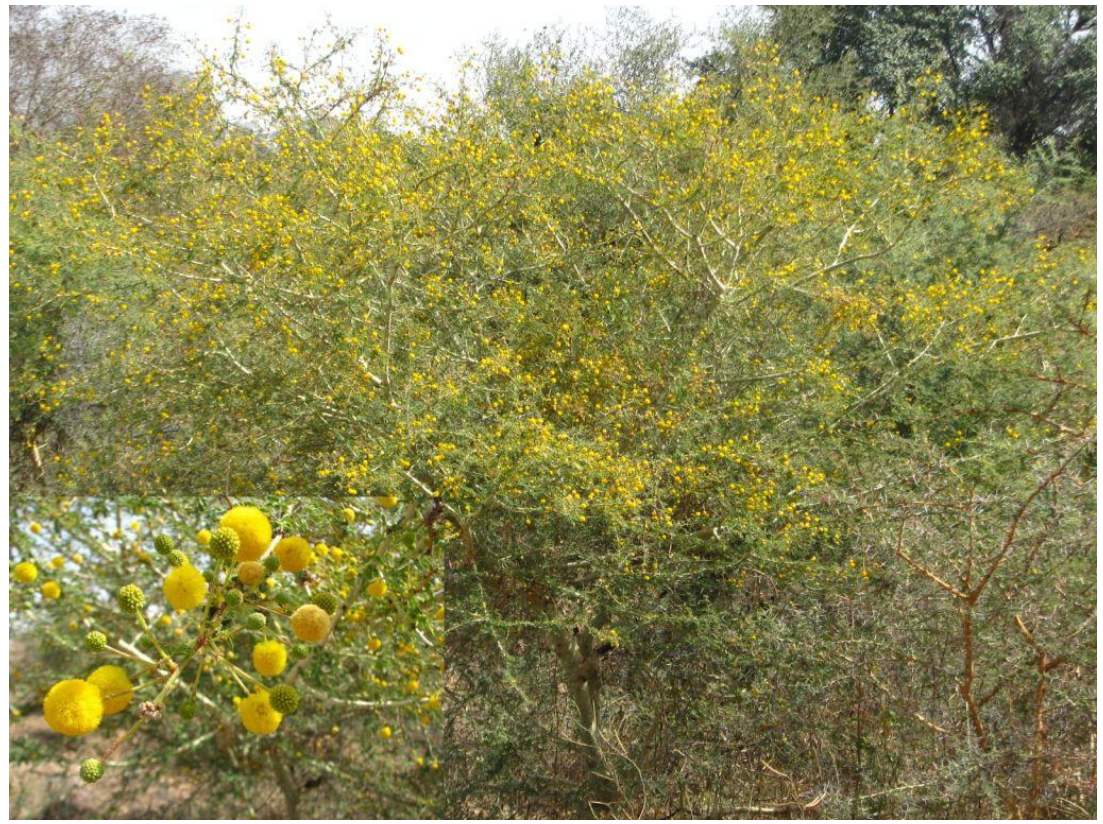

Figure 2. Acacia seyal Del.

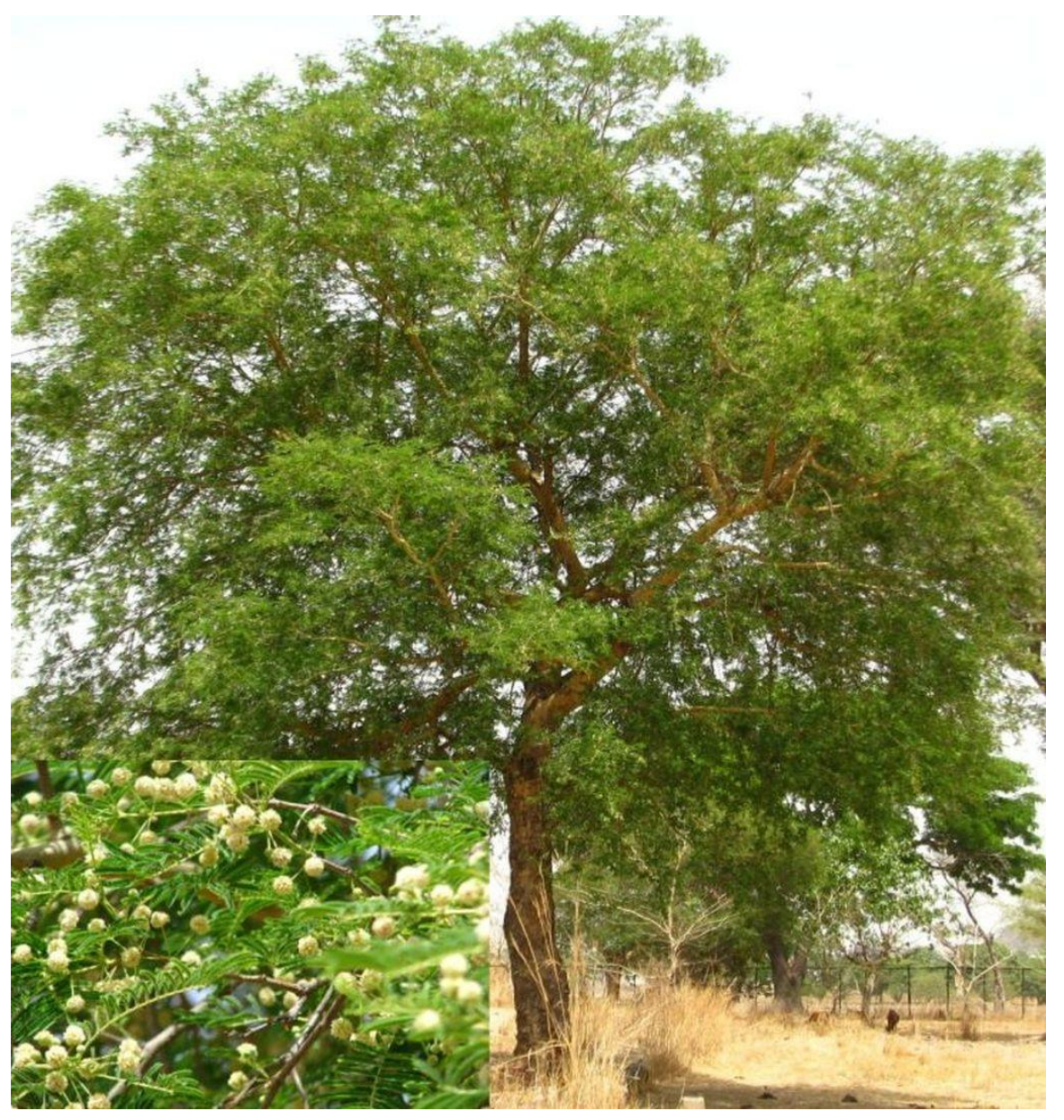

Figure 3. Acacia sieberiana DC. 


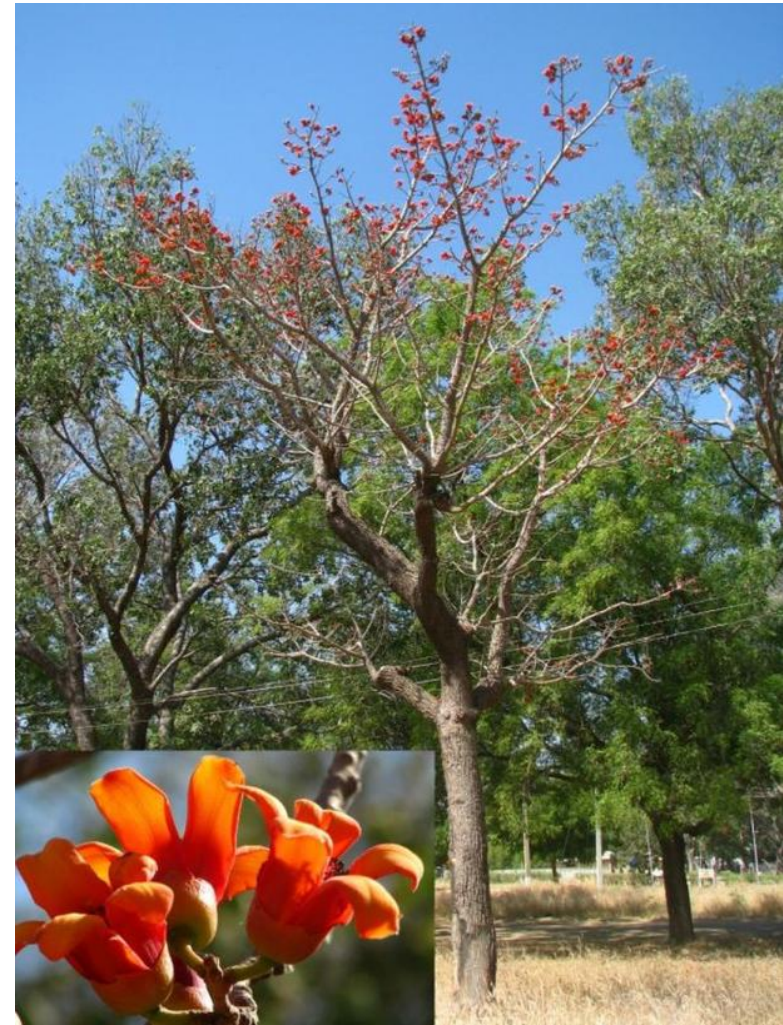

Figure 4. Bombax costatum Pellegr. \& Vuill.

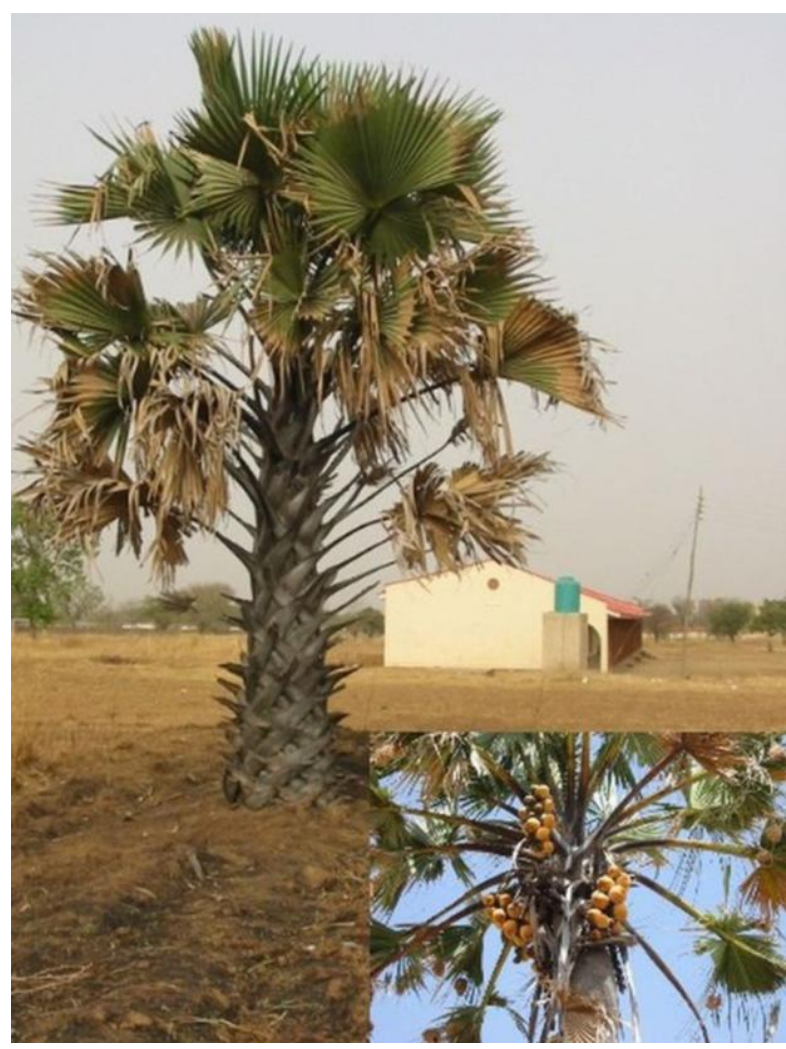

Figure 5. Borassus aetheopum Mart.

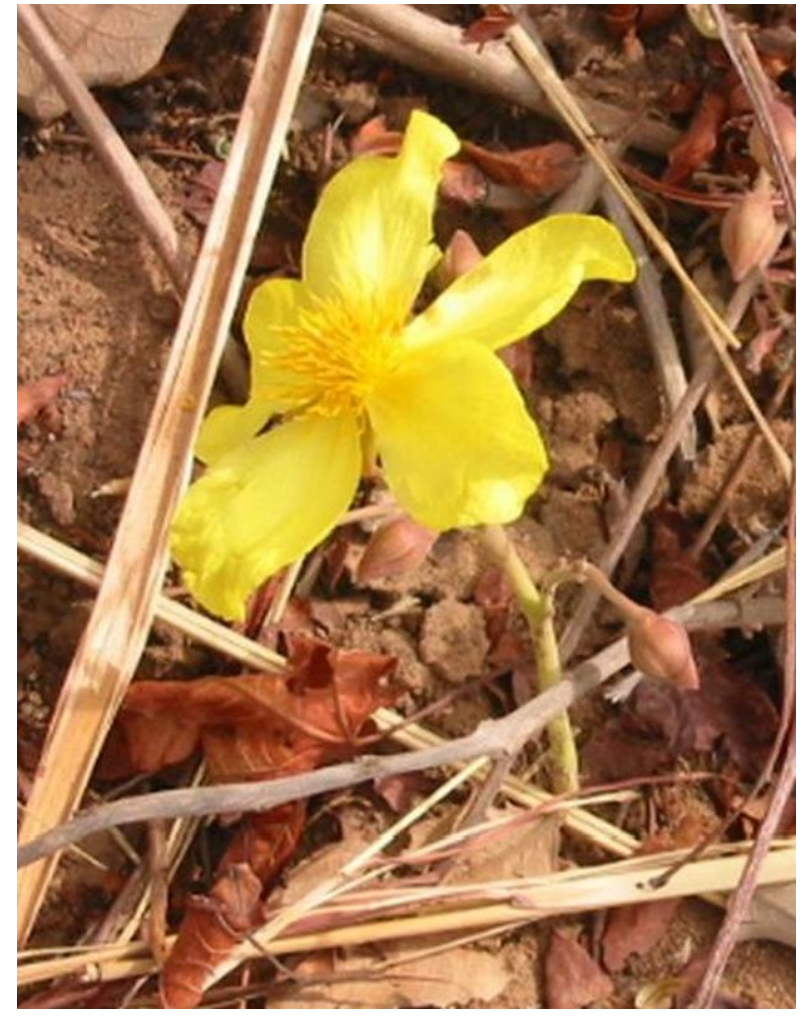

Figure 6. Cochlospermum tinctorium A. Rich.

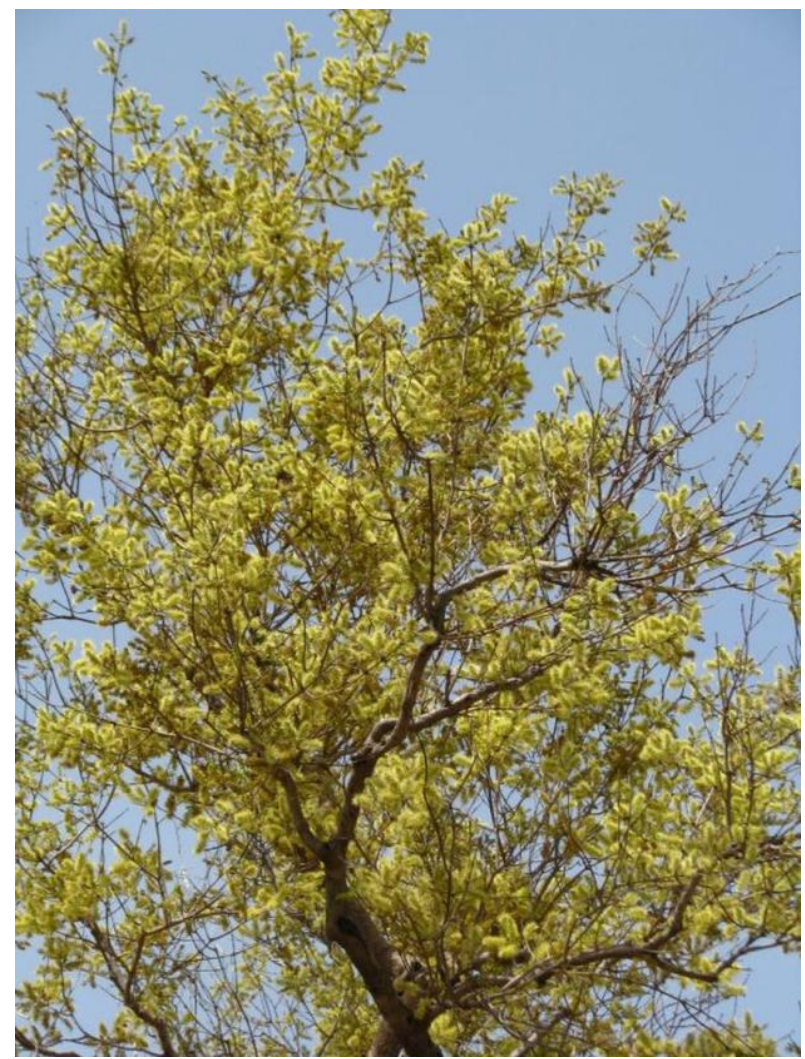

Figure 7. Combretum molle R. Br. ex G. Don. 


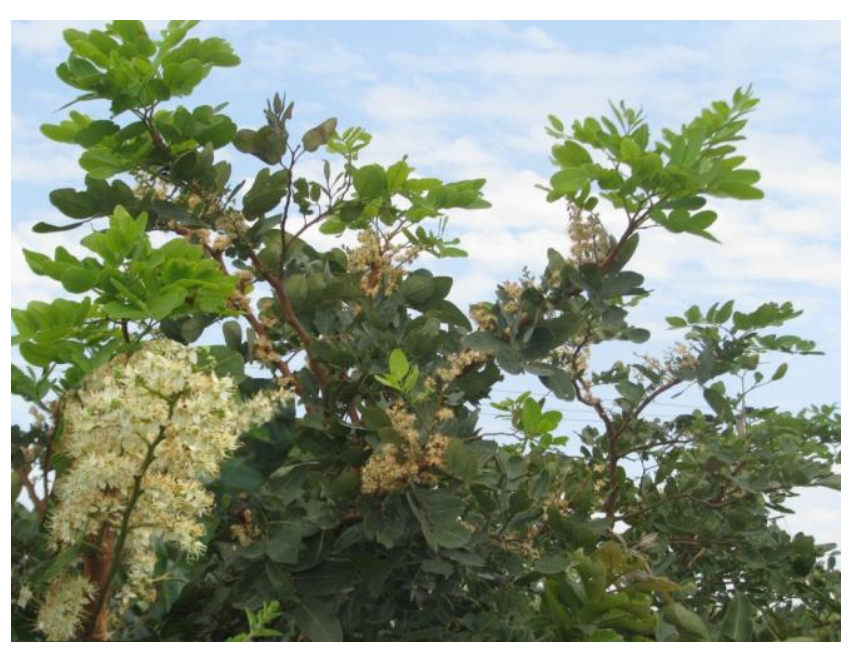

Figure 8. Detarium microcarpum Guill \& Perr.

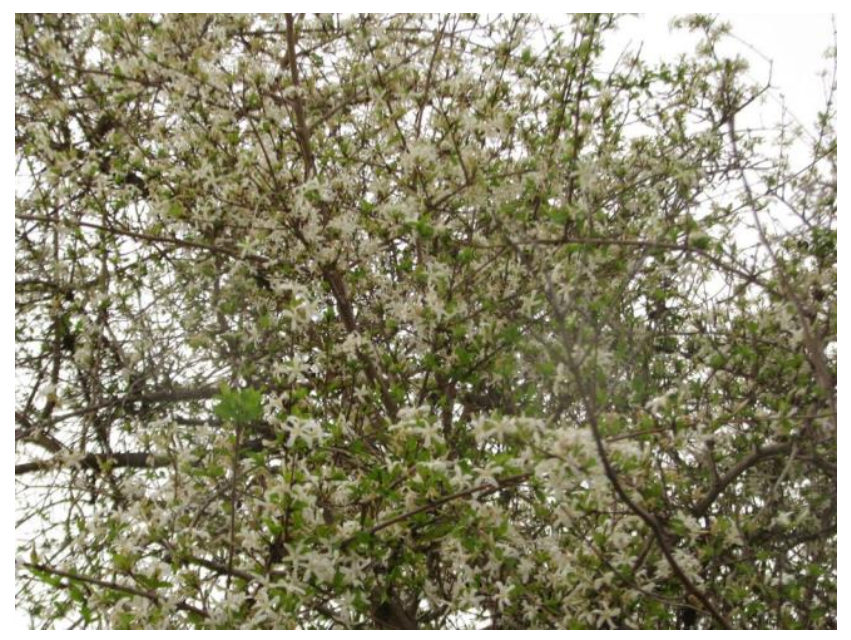

Figure 9. Feretia apodanthera Del.

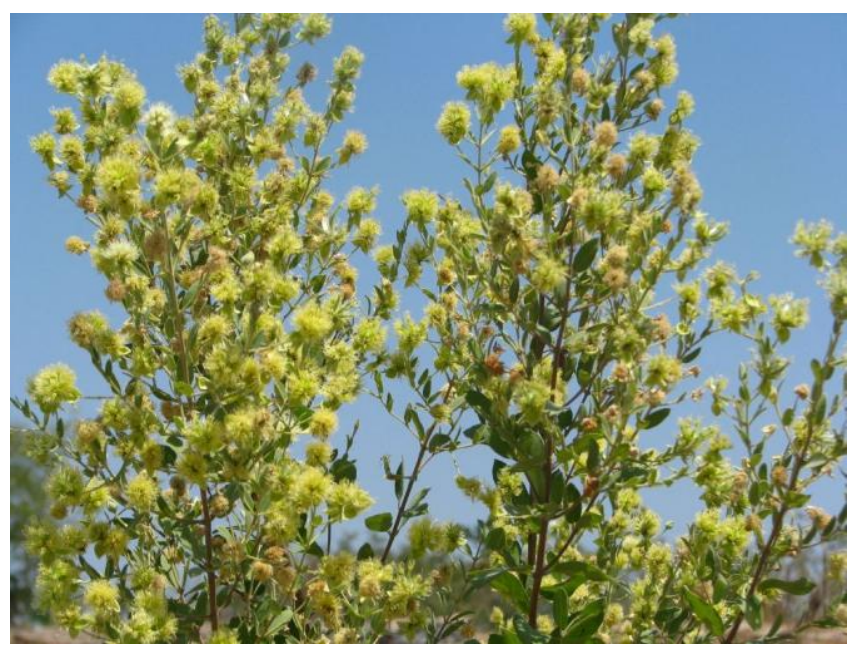

Figure 10. Guiera senegalensis J.F.Gmel.

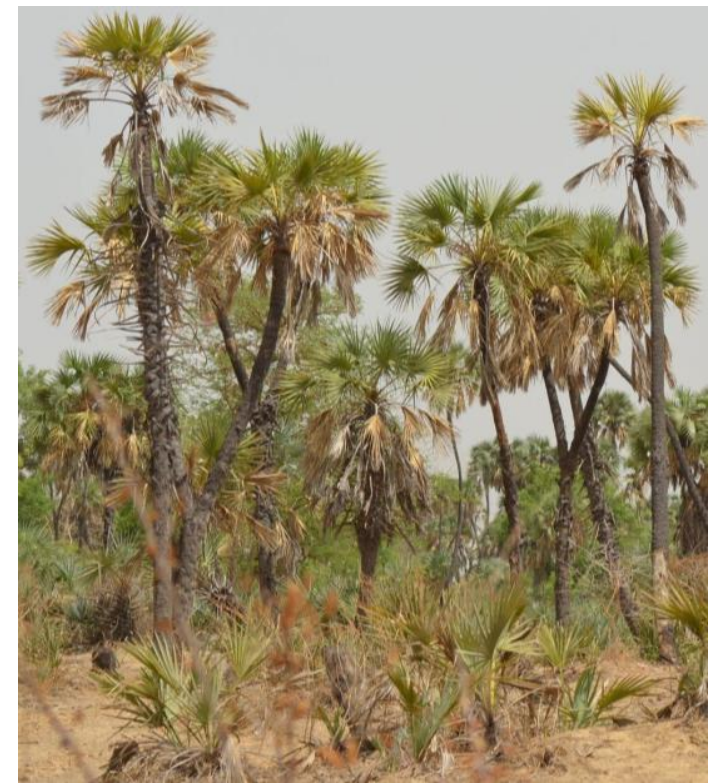

Figure 11. Hyphaene thebaica Mart.

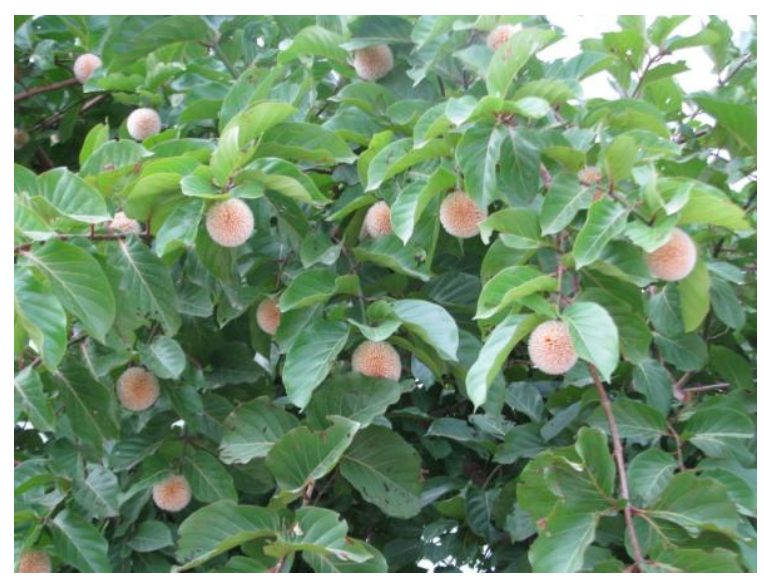

Figure 12. Nauclea latifolia Smith.

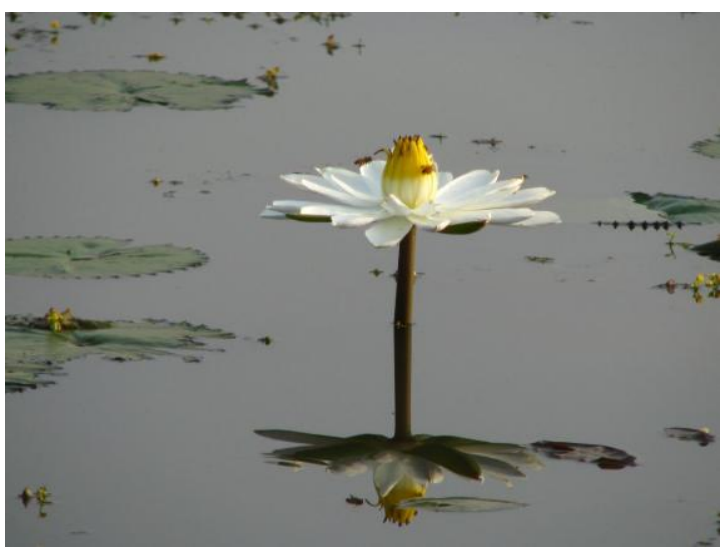

Figure 13. Nymphaea lotus L. 
Afr. J. Plant Sci.

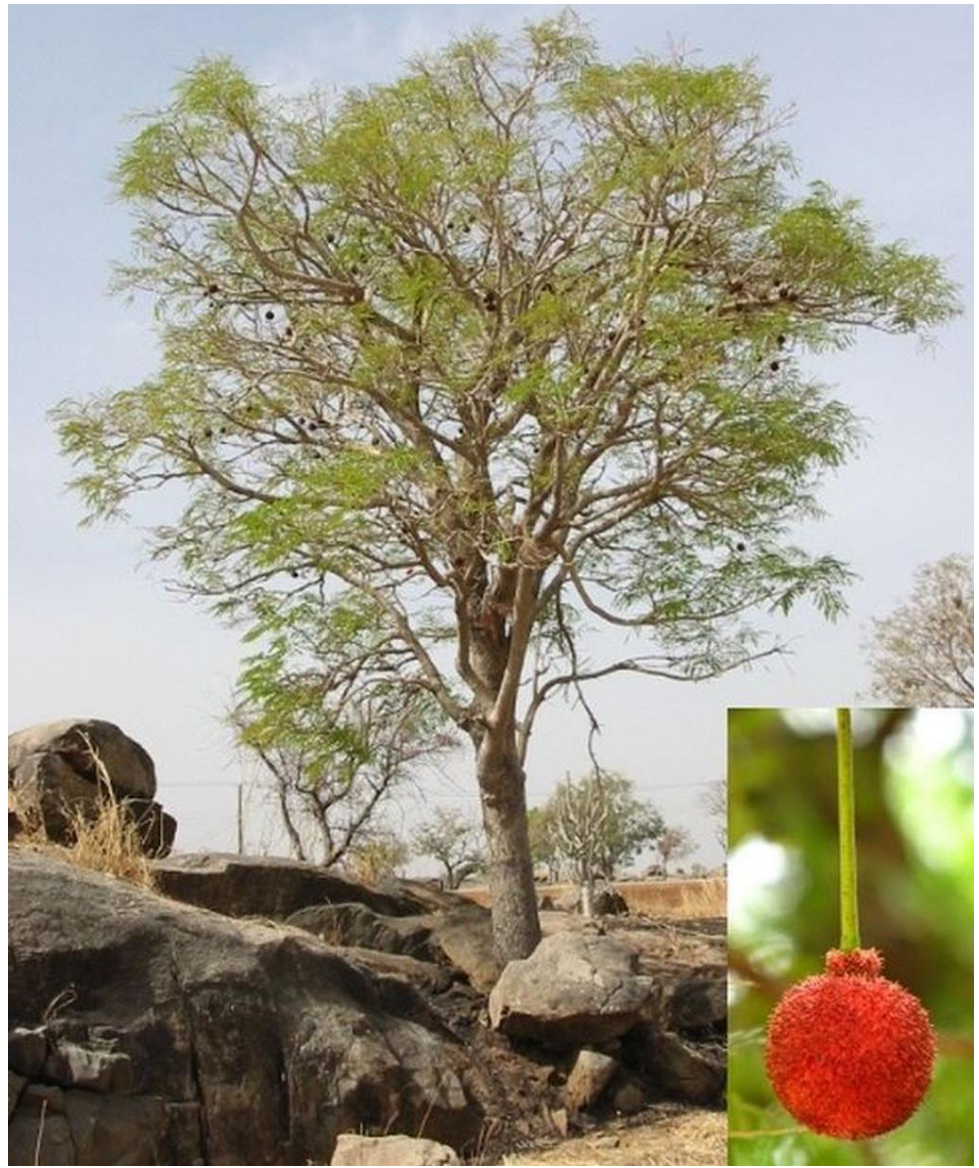

Figure 14. Parkia biglobosa (Jacq) Benth.

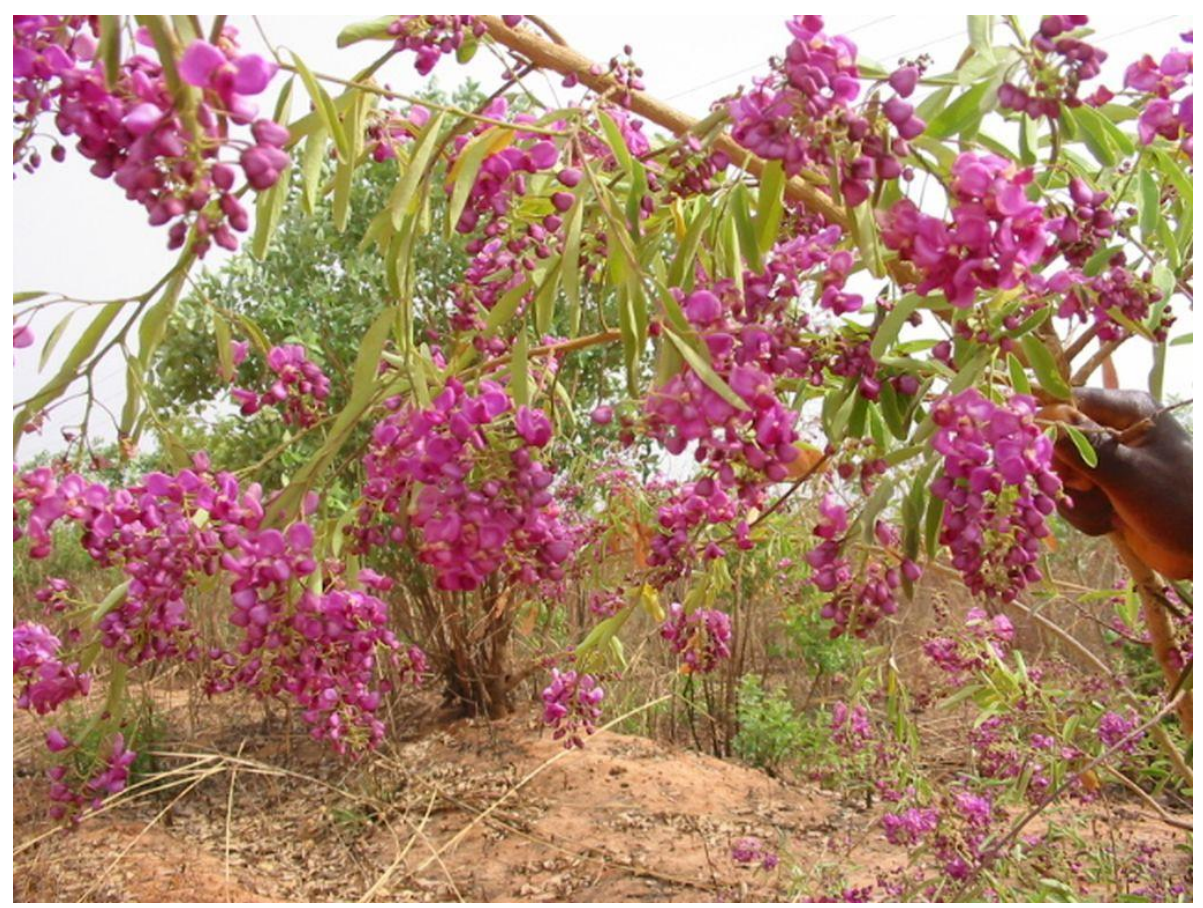

Figure 15. Securidaca longepedunculata Fres. 


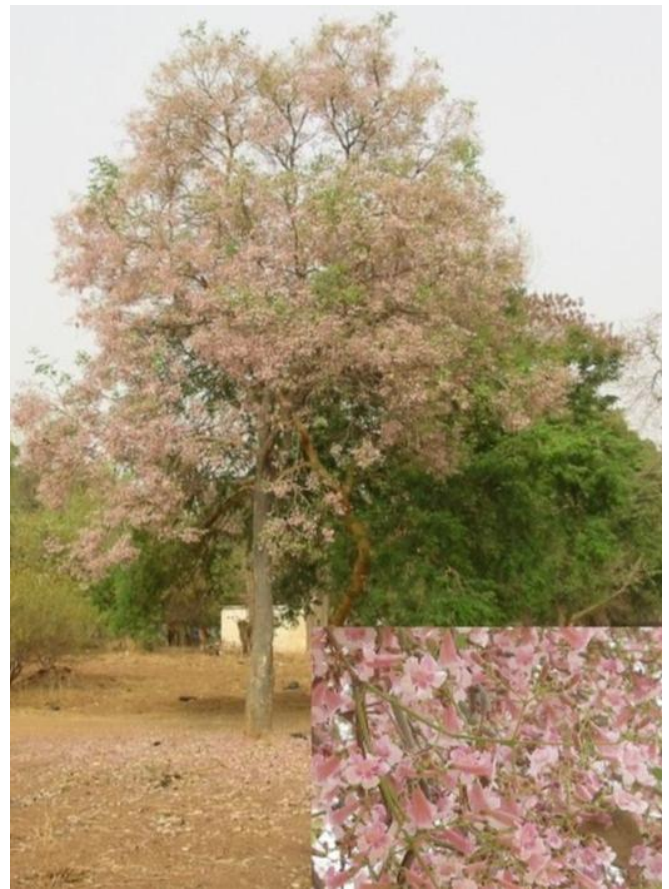

Figure 16. Stereospermum kunthiamum Cham.

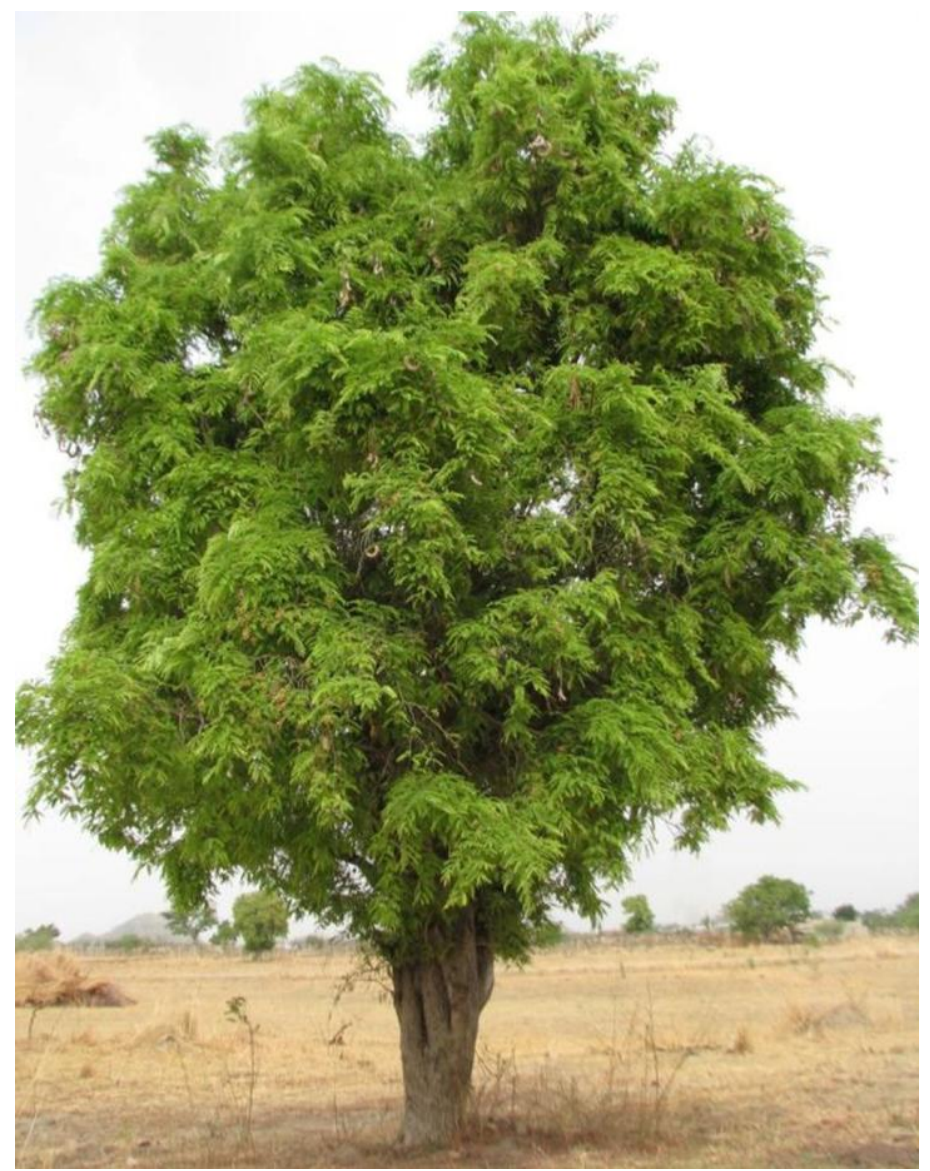

Figure 17. Tamarindus indica $\mathrm{L}$. 


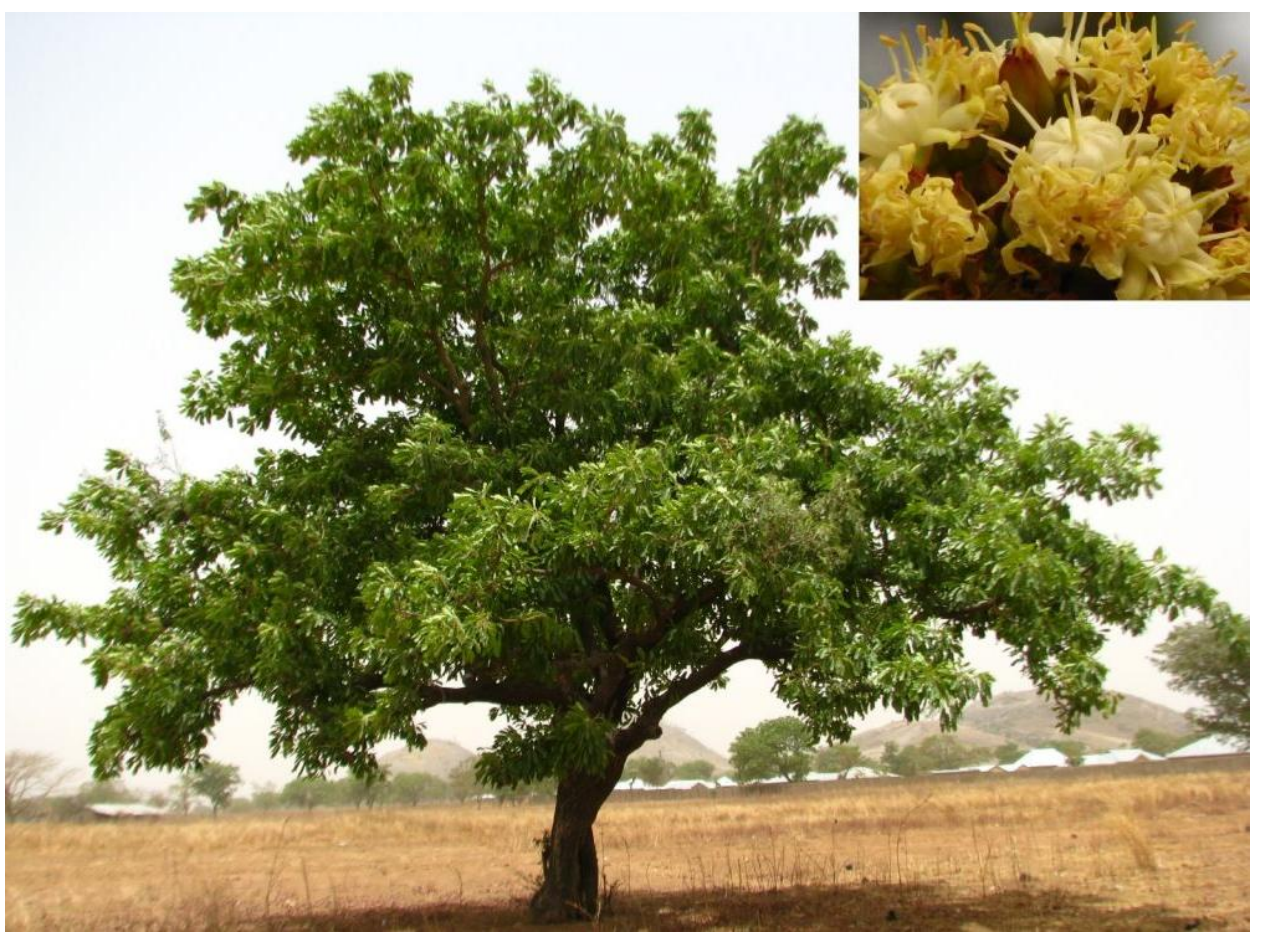

Figure 18. Vitellaria paradoxa Gaertn.

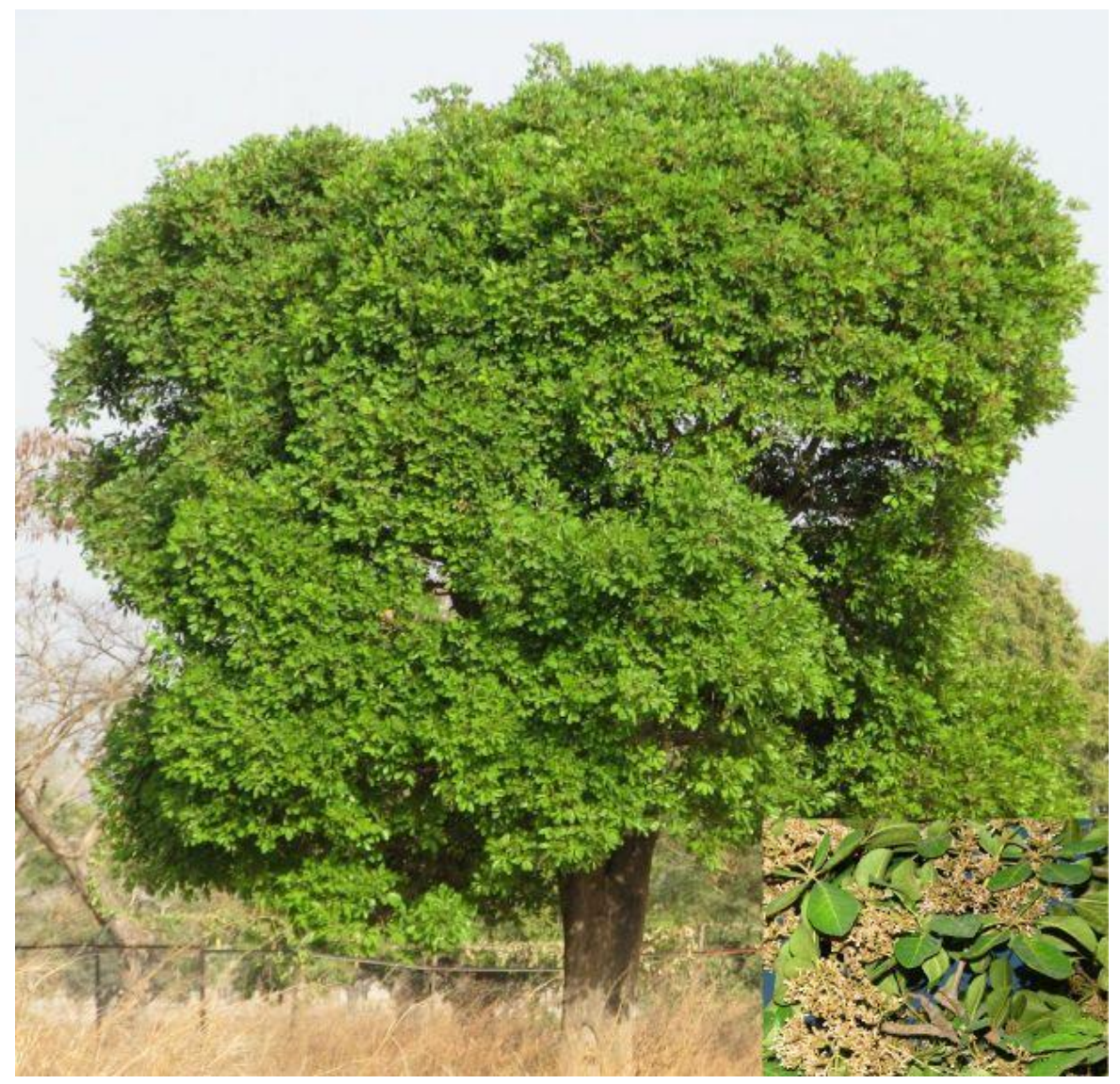

Figure 19. Vitex doniana Sweet. 


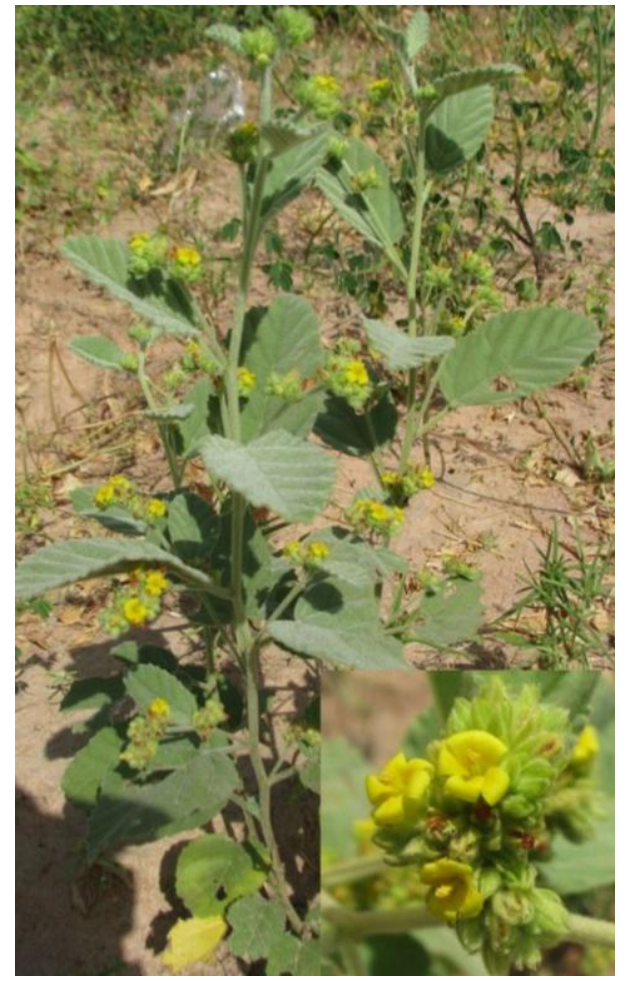

Figure 20. Waltheria indica L.

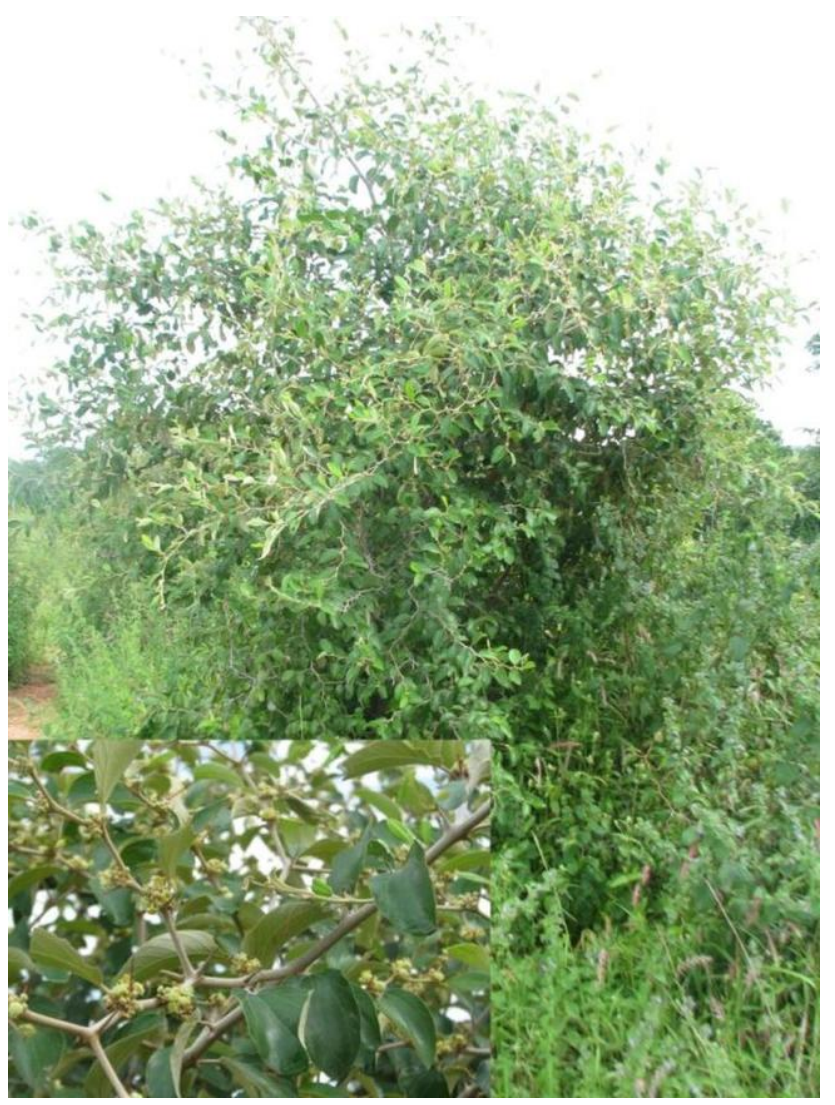

Figure 21. Ziziphus mauritiana Lamarck. 


\section{REFERENCES}

Abdullahi G, Sule H, Chimoya IA, Isah MD (2011). Diversity and relative distribution of honeybees foraging plants in some selected reserves in Mubi region, Sudan Savannah ecological zone of Nigeria. Adv. Appl. Sci. Res. 2(5):388-395.

Adekanmbi O, Ogundipe O (2009). Nectar Sources for the honey bee (Apis mellifera adansonii) revealed by pollen content. Not. Bot. Horti Agrobot. Cluj-Napoca 37(2):211-217.

Anonymous (2013). FAOSTAT. Food and agricultural commodities production. Available online at: http://faostat.fao.org/site/339/default.aspx Accessed on 19th May 2013.

Ayansola AA, Davies BA (2012). Honeybee floral resources in southwestern Nigeria. J. Biol. Life Sci. 3(1):127-138.

Dukku UH (2003). Acacia ataxacantha: A nectar plant for honeybees between two dearth periods in the Sudan Savanna of Northern Nigeria. Bee World 84(1):32-34.

Ebenezer IO, Olugbenga MT (2010). Pollen characterisation of honey samples from north central Nigeria. J. Biol. Sci. 10(1):43-47.

Ghazanfar SA (1989). Savanna plants: An illustrated guide. Macmillan. London and Basingstoke. p. 227.

Hepburn HR, Radloff SE (1998). Honeybees of Africa. Springer-Verlag, Berlin Hedelberg. pp. 370

Hopkins B, Stanfield DP (1966). A field key to the Savanna trees of Nigeria. Ibadan University Press, Ibadan, Nigeria. p. 39.

Keay RWJ, Onochie CFA, Stanfield DP (1964). Nigerian Trees, Vol.II. Department of Forest Research, Ibadan, Nigeria. p. 495.

Köppler K, Vorwohl G, Koeniger N (2007). Comparison of pollen spectra collected by four different subspecies of the honey bee Apis mellifera. Apidologie 38:341-353.
Mbah CE, Amao AO (2009). Natural foods and feeding habits of the African honey bee Apis mellifera adansonii Latrielle (1804) in Zaria, Northern Nigeria. Sci. World J. 4(1):11-14.

Morse R, Calderone N (2000). The value of honeybees as pollinators of US crops in 2000. Bee Culture, March 2000, pp.1-15.

Nnamani CV, Uguru AN (2012). Genetic diversity of honey producing plants under changing climate in Southern Nigeria: Need for conservation to improve food security and livelihood option. Third RUFORUM Biennial Meeting 24 - 28 September 2012, Entebbe, Uganda. pp.1455-1458.

Ramanujam CGK, Kalpana TP (1992). Tamarindus indica L.: An important forage plant for Apis florea in south central India. Apidologie 23:401-413.

Teklay A (2011). Seasonal Availability of common bee flora in relation to land use and colony performance in Gergera Watershed, Atsbi Wembwrta District, Eastern Zone of Tigray, Ethiopia. M.Sc. Thesis, Hawassa University, Wondo Genet College of Forestry and Natural Resources, Wondo Genet, Ethiopia. 